\title{
Growth of Mycobacterium lepraemurium Maintained in Cultures of Rat Fibroblasts
}

\author{
By ELIZABETH W. GARBUTT, R. J. W. REES AND YVONNE M. BARR \\ The National Institute for Medical Research, Mill Hill, London, N.W. \%.
}

(Received 3 June 1961)

\begin{abstract}
SUMMARY
Hitherto only limited multiplication of Mycobacterium lepraemurium has been obtained in cell cultures; in cultures of rat fibroblasts (strain $14 \mathrm{pf}$ ) used by Garbutt, Rees \& Barr (1958) growth of bacilli was limited to one or two generations. The present work shows that more continuous intracellular growth of $\boldsymbol{M}$. lepraemurium can be achieved in cultures of rat fibroblasts by repeatedly subculturing the infected cells. The results suggest that multiplication of the bacteria is maintained only when a high proportion (50-75\%) of the infected cells are transferred at each subculture. In one experiment, continued for 156 days, the increase in the number of bacteria was equivalent to 8 generations and the bacteria recovered from the cells were still infectious for mice. Quantitative electron microscopy also was used to follow the viability of bacteria from the cell cultures.
\end{abstract}

\section{INTRODUCTION}

Although rat and human leprosy bacteria have not been cultivated in bacteriological type media there have been several reports of significant though limited multiplication of the rat leprosy organism, Mycobacterium lepraemurium, in tissue cultures. Rees \& Wong (1958) and Wallace, Elek \& Hanks (1958) showed that $M$. lepraemurium multiplied in cultures of spleen tissue and cells, respectively, obtained from animals previously infected with rat leprosy. Rees \& Wong (1958) showed that multiplication did not occur in otherwise identical cultures to which had been added high concentrations of antileprosy drugs (streptomycin, isoniazid). Primary cultures of explanted tissue or cells from previously infected animals seemed to offer the greatest chance of success because the bacteria would remain undisturbed in the specific host cells. On the other hand, such cultures could not be maintained in a healthy state for the long-term studies required for continuous multiplication of a slowly growing organism like $\boldsymbol{M}$. lepraemurium which has a mean generation time of 10-13 days (Rees, 1957b). Such studies required the use of established lines of cells which could be infected in vitro. Wallace et al. (1958) obtained limited multiplication of $M$. lepraemurium in mouse fibroblasts (L strain) in the presence of high concentrations of hydrocortisone. Unfortunately the concentration of hydrocortisone required was damaging to the cells and the conditions therefore were not suitable for maintaining long-term cell cultures. Garbutt et al. (1958) obtained multiplication of rat leprosy bacteria in rat fibroblasts (strain 14 pf) without the use of hydrocortisone. Multiplication in the majority of these cultures was confined to one generation, but in three experiments greater increases were 
obtained (3.1-, 4.4- and 5.5-fold, respectively). No growth occurred in the cultures to which streptomycin and isoniazid had been added. In general, the initial rate of multiplication of the bacteria in all these tissue cultures corresponded closely to that obtained in vivo in the mouse or rat, but growth was limited to one or at most two generations, even when the tissue cultures were maintained for $\mathbf{4 0}$ days. In cultures of the primary type where tissues were obtained direct from animals with rat leprosy, the cells were deteriorating by the twelfth day. Even in the experiments with established cell lines, the cells deteriorated simply because the methods used were adopted to obtain accurate enumeration of the bacteria and did not necessarily provide the best conditions for maintaining healthy cells. For example, the medium was renewed infrequently, if at all, and the cells were not transferred. We report here more successful growth of $\boldsymbol{M}$. lepraemurium in cultures of rat fibroblasts maintained by repeated subculture of cells infected in vitro.

\section{MATERIALS}

Cell cultures. A non-malignant line of rat fibroblast cells, strain 14 pf (Gey, Hanks \& Barrett, 1948; Ehrmann \& Gey, 1953) was used throughout. Cultures of 14 pf cells were received from Dr G. O. Gey in 1956 and 1958. The cell line had been maintained in medium containing human cord serum since it was first established in 1938, and all attempts in this laboratory to replace human cord serum by horse or calf serum were unsuccessful. Stock cultures of 14 pf were maintained therefore in $50 \%(\mathrm{v} / \mathrm{v})$ non-inactivated human cord serum (HCS 50) and 50\% Hanks's balanced salt solution (BSS 50) with 100 units penicillin and $100 \mu$ g. streptomycin/ ml. Cells were grown for 7 days, with twice-weekly changes of medium, in Porter flasks or in Pyrex feeding-bottles, and were subcultured by trypsinization $(0.5 \%, \mathrm{w} / \mathrm{v}$, trypsin, Difco $1: 250$ ).

Suspensions of Mycobacterium lepraemurium. The Douglas strain of Mycobacterium lepraemurium (Balfour-Jones, 1937) was used throughout. Liver from mice, albino $\mathbf{P}$ strain, infected intravenously $8-10$ weeks previously with a partially purified suspension of bacteria (Rees, $1957 a$ ), was minced with scissors and ground in a mortar to a smooth suspension. All procedures were carried out under sterile conditions. To increase the susceptibility of the mice to $\boldsymbol{M}$. leprcamurium the animals were given suramin (1 mg.) subcutaneously once weekly. The suspensions were usually prepared in $1 \%(\mathrm{w} / \mathrm{v}$ ) albumin (bovine fraction $\mathrm{V}$ ) in $\mathbf{0 . 8 5} \%(\mathrm{w} / \mathrm{v}$ ) $\mathrm{NaCl}$ solution (albumin-saline). However, in some of the earlier experiments the suspensions were prepared in $0.5 \%(w / v)$ yeast supplement (Difco) and $5 \%$ albumin $(\mathrm{w} / \mathrm{v})$ in phosphate buffer $(\mathrm{M} / \mathbf{1 5}, \mathrm{pH} 7 \cdot 4)$. The crude suspension was centrifuged at $1500 \mathrm{rev} . / \mathrm{min}$. $(400 \mathrm{~g})$ for $5 \mathrm{~min}$. to remove tissue fragments and clumps of bacteria. The supernatant fluid was removed, centrifuged at $5000 \mathrm{rev} . / \mathrm{min}$. $(5000 \mathrm{~g})$ for $5 \mathrm{~min}$. and the resulting supernatant fluid discarded.

The sediment was carefully resuspended in albumin saline and counted by the method described by Hart \& Rees (1960). In most of these suspensions the bacteria were well dispersed and predominantly single organisms. All the procedures were carried out in the cold $\left(2-4^{\circ}\right)$. Immediately before adding to the cell cultures the stock suspension of $\boldsymbol{M}$. lepraemurium was diluted in BSS or Parker's medium 199 (Morgan, Morton \& Parker, 1950) to give a standard suspension containing 
2-4 $\times 10$ bacteria/ml. A fresh suspension was prepared for each experiment and used to infect the cell cultures within $4 \mathrm{hr}$. of removal of the tissue from the mouse.

Infection of cell cultures with Mycobacterium lepraemurium. For each experiment a bottle of 14 pf cells was grown for 6-10 days to obtain a confluent sheet of cells. Four days before the experiment began $6 \mathrm{ml}$. of fresh medium was added to the bottle. Penicillin was decreased from 100 to 25 units $/ \mathrm{ml}$. and streptomycin omitted.

Before infecting the cells with Mycobacterium lepraemurium the medium was removed and the cells washed with BSS for $20 \mathrm{~min}$. at $37^{\circ}$ to remove excess serum which might be damaging to the bacteria (Hanks \& Gray, 1954). The washed cells were then infected with Mycobacterium lepraemurium by adding $0.6 \mathrm{ml}$. bacterial suspension to $6 \mathrm{ml} .0 .0125 \%(\mathrm{w} / \mathrm{v})$ albumin in BSS. Penicillin was added to a final concentration of 25 units $/ \mathrm{ml}$. and the cells incubated at $37^{\circ}$ for $24 \mathrm{hr}$. During this period over $80 \%$ of the cells ingested bacteria. After incubation the suspension of $\boldsymbol{M}$. lepraemurium was removed from the bottle and the cells were recovered from the glass by adding $4 \mathrm{ml}$. trypsin and incubating for $10-15 \mathrm{~min}$. at $37^{\circ}$. The trypsinized cells were thoroughly rinsed with BSS and lightly centrifuged to remove the extracellular bacteria.

Maintenance of cell cultures infected with Mycobacterium lepraemurium. The washed infected cells were resuspended in sufficient medium (HCS50 BSS50+ 25 units penicillin $/ \mathrm{ml}$.) to give a confluent sheet of cells in the appropriate containers (half test tubes, Porter flasks, or bottles) depending upon the design of the experiment. The cells were carefully maintained in suspension by agitation and were rapidly distributed, $1 \mathrm{ml}$. each to half test tubes or Porter flasks and $6 \mathrm{ml}$. to bottles. All infected cell cultures were incubated at $34^{\circ}$ in order to slow the growth rate of the cells and to decrease the frequency at which the medium was changed. The cultures were examined every 2-3 days and the medium was changed every 1012 days. Generally the cells were transferred by trypsinization every 21 days, the actual time being determined by the appearance of the cells. When the cells continued in very good condition transfers were delayed as long as possible, and by repeatedly subculturing $14 \mathrm{pf}$ cells infected with $M$. lepraemurium, healthy populations of cells were maintained up to 156 days.

Quantitative assessment of Mycobacterium lepraemurium in cell cultures. Quantitative methods were used to follow the total bacterial populations in the cell cultures by counting the acid-fast bacteria (Ziehl-Neelsen method) present in samples taken from the cultures at intervals through the experiment. The samples for counting were as follows: $(a)$ base-line sample, taken at the beginning of the experiment or at the beginning of each subsequent transfer; $(b)$ trypsinized sample, taken when the cells were trypsinized at the end of each culture period; $(c)$ fluidchange sample, consisting of all the medium removed before adding fresh medium to the cultures. In order to follow the total bacterial populations in the cultures all volumes of cell suspensions, media removed at the time of renewal and samples taken for counting, were measured accurately. A standard procedure was used to prepare the samples for counting, but it was first necessary to decrease the high concentration of serum present, to prevent masking of the acid-fast bacteria in smears stained with carbol fuchsin. Measured samples $(2-10 \mathrm{ml}$.) were therefore first centrifuged in sterile Lusteroid tubes at $5000 \mathrm{rev} . / \mathrm{min}$. $(5000 \mathrm{~g})$ for $30 \mathrm{~min}$. To standardize the conditions of centrifugation, each sample where necessary was 
made up to $10 \mathrm{ml}$. with sterile distilled water. As much as possible of the supernatant fluid was removed with a Pasteur pipette without disturbing the deposit and $1 \mathrm{ml} \cdot 0 \cdot 1 \%(\mathrm{w} / \mathrm{v})$ albumin in water added. To count accurately the total number of bacteria present in each culture it was first necessary to release completely the bacteria from the cells and so obtain a well-dispersed suspension of organisms. This was achieved in a single operation by exposing the tubes to ultrasonic vibration $(300 \mathrm{kc}$. $/ \mathrm{sec}$. for $30 \mathrm{sec}$ ), a procedure which has been shown to disrupt the cells completely without damage to the intracellular bacteria (Wong, 1957). Immediately after exposure to ultrasonic vibration the sample was accurately re-measured, $0.05 \mathrm{ml}$. formaldehyde added, and the number of acid-fast bacteria counted by the method of Hart \& Rees (1960). Standard spread smears were prepared from each sample and counted in quadruplicate. The spread smears were almost cell-free and the bacteria usually single. Whenever it was necessary to re-count a sample it was re-exposed to ultrasonic vibrations to disperse the bacteria.

Examination of Mycobacterium lepraemurium in the electron microscope. It has been shown that degenerate (dead) forms of $M$. lepraemurium can be identified in the electron microscope and that this technique is useful for following the survival time of these bacilli in tissue cultures (Rees, Valentine \& Wong, 1960). In the present experiments selected samples of cultures for counting were also examined in the electron microscope for determining the proportion of dead organisms. To ensure that a sufficiently clean specimen was obtained for electron microscopy $10 \mathrm{ml}$. of sterile distilled water was added to each sample and centrifuged at $5000 \mathrm{rev} . /$ min. for $30 \mathrm{~min}$. The supernatant fluid was removed leaving about $0.5 \mathrm{ml}$. and the deposit re-suspended by exposure to ultrasonic vibrations for $30 \mathrm{sec}$. The proportion of degenerate forms was determined, when possible, from 100 organisms.

Infectivity of Mycobacterium lepraemurium recovered from tissue cultures. Infectivity of the bacteria recovered from selected samples of cell cultures was determined in mice by the method of Rees et al. (1960). The samples were prepared by the same method as used for counting $M$. lepraemurium, but after the bacteria had been released from the cells, by exposure to ultrasonic vibrations, no formaldehyde was added. Five or 6 mice (albino $P$ strain) were used for each sample tested. Standard doses were inoculated subcutaneously over the abdomen and the site inspected and palpated monthly for the presence of a leprosy nodule.

\section{RESULTS}

Altogether 20 cultures of 14 pf cells were infected with Mycobacterium lepraemurium, but the cells in only 11 experiments were maintained successfully for more than one or two subcultures. Of the 11 experiments in which the cells were successfully subcultured, 8 were maintained by retaining $12 \cdot 5-25 \%$ of the infected cells at each transfer (type A experiment) and 3 by retaining $40-80 \%$ of the cells (type $\mathrm{B}$ experiment).

\section{Type $A$ experiment}

Thirteen cultures of this type were infected with Mycobacterium lepraemurium; 5 cultures were discarded early, 4 because of contamination and one because of poor initial uptake of bacteria. Of the 8 cultures which were successfully maintained 
through several transfers, limited multiplication of bacteria was observed in 4 of them. The results of a representative experiment are now given in detail.

In the experiment the bottle of cells was infected with $1 \cdot 1 \times 10^{9}$ bacteria. After incubation overnight the cells were trypsinized and put into Porter flasks. Seven Porter flasks were used until day 152 and from then until the termination of the experiment (at day 195) the cells were maintained in a Pyrex feeding bottle. Fluid changes were carried out every 10 days and transfers at about every 20 days.

Table 1. Percentage of uninfected and infected rat fibroblast cells (strain 14pf) showing the distribution of intracellular acid-fast bacteria (type A experiment)

\begin{tabular}{|c|c|c|c|c|c|}
\hline \multirow{3}{*}{$\begin{array}{l}\text { Culture } \\
\text { period } \\
\text { (days) }\end{array}$} & \multicolumn{5}{|c|}{ No. of bacteria/cell } \\
\hline & 0 & $1-2$ & $3-5$ & $6-10$ & $>10$ \\
\hline & \multicolumn{5}{|c|}{ Infected cells $(\%)$} \\
\hline 0 & 2 & 1 & 2 & 12 & 83 \\
\hline $\mathbf{3 1}$ & 36 & 27 & 17 & 9 & 11 \\
\hline 51 & 42 & 15 & 12 & 13 & 18 \\
\hline 71 & 71 & 14 & 7 & $\mathbf{3}$ & $\mathbf{5}$ \\
\hline 92 & 82 & 13 & 2 & 2 & 1 \\
\hline 113 & 94 & 5 & $\mathbf{0}$ & $\mathbf{0}$ & 1 \\
\hline 133 & 94 & 6 & 0 & $\mathbf{0}$ & $\mathbf{0}$ \\
\hline 152 & 92 & 8 & $\mathbf{0}$ & $\mathbf{0}$ & $\mathbf{0}$ \\
\hline 173 & 90 & 10 & $\mathbf{0}$ & $\mathbf{0}$ & $\mathbf{0}$ \\
\hline 195 & 100 & 0 & $\mathbf{0}$ & $\mathbf{0}$ & $\mathbf{0}$ \\
\hline
\end{tabular}

In an attempt to maintain the cells in the best possible condition by avoiding overcrowding in the flasks about one-quarter of the total cell population was used for each transfer. The distribution of bacteria in the cells was followed throughout the experiment by counting the acid-fast bacteria in stained smears prepared from a sample of cells taken at each transfer (Table 1). These direct smears showed a high initial uptake of bacteria by the cells (more than $90 \%$ infected) and also a steady decrease in the proportion of infected cells. Total bacterial counts were made at each transfer; the results are shown in Table 2 . There were 4 culture periods in which there were about twofold increases in the number of bacteria. The total increase was $24 \cdot 75$-fold, or 4.5 generations in 152 days, giving an average generation time of 33.8 days. However, during 92 of the 152 days little or no multiplication of bacteria occurred; this accounts for the long generation time as compared with that found in vivo. When the generation time is calculated only on the 60 days in which significant multiplication occurred, then it would be 13.3 days. On days 51 and 71 the base-line samples were scored by electron microscopy for \% degenerate (dead) organisms. When the number of degenerate organisms is subtracted from the total base-line count and from the subsequent trypsinized sample count (it was assumed that dead bacteria remained intact in the culture), then a greater apparent increase is obtained. On day 71 the apparent increase is $\mathbf{2} \cdot 3$-fold whereas, allowing for the degenerate bacteria, the estimated increase is $\mathbf{3} \cdot \mathbf{1 - f o l d}$.

Viability of organisms recovered from cell cultures. On day 92 a suspension of bacteria recovered from the cell cultures was injected subcutaneously into 6 mice. The mice were palpated at regular intervals; all subsequently developed typical leprosy nodules. 
Re-infected cell cultures. Six cultures of type A experiment were re-infected with a freshly prepared suspension of Mycobacterium lepraemurium at a time when only a few bacteria remained from the first infection. The cells were re-infected at periods ranging from 40 to 200 days after the primary infection. Five cultures were successfully maintained for a further one or more subcultures and in three a limited degree of multiplication of bacteria was observed. In a further four cultures an attempt was made to follow only the quality of the bacteria as determined in the electron microscope, throughout the experiment. However, this was not successful because the $\%$ of cells retained for transfer was too low; consequently there were insufficient bacteria for assessment.

Table 2. 'Apparent' and 'estimated' increase in the number of bacteria in cultures of rat fibroblast cells (strain $14 \mathrm{pf}$ ) during each subculture (type A experiment)

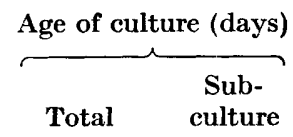

$\begin{array}{rr}0 & \\ 31 & 3 \\ 31 & \\ 51 & 20 \\ 51 & \\ 71 & 20 \\ 71 & \\ 92 & 2 \\ 92 & \\ 113 & 2 \\ 113 & - \\ 133 & 20 \\ 133 & \\ 152 & 19\end{array}$

$$
\begin{aligned}
& \text { Cells } \\
& \text { trans- } \\
& \text { ferred } \\
& (\%)
\end{aligned}
$$

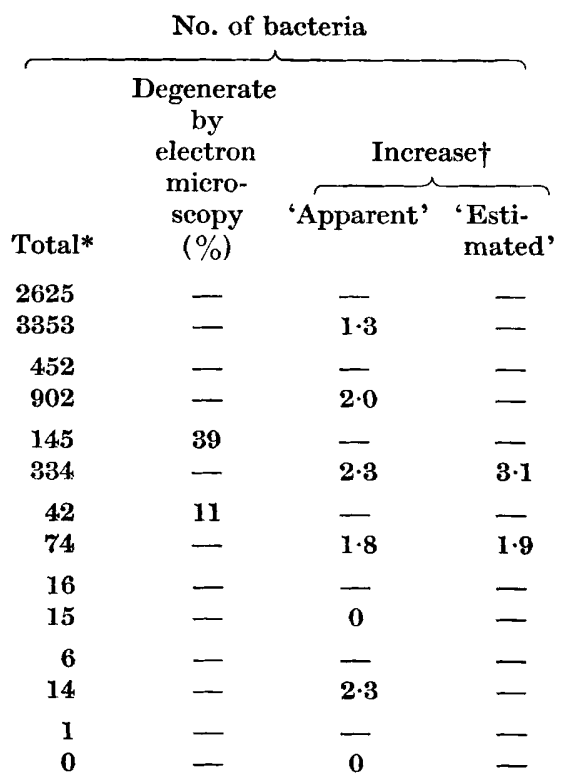

B.L. = base-line sample, $\mathbf{T} .=$ trypsinized sample, $*=$ total number of acid-fast bacteria $(X \log 5 \cdot 0755) ; \dagger=$ 'Apparent' increase derived from (total count T/total count B.L.); ' estimated' increase derived from (total count T-no. degenerate bacilli in B.L.); (total count B.L. - no. degenerate bacilli in B.L.).

\section{Type $B$ experiments}

Seven cultures of this type were infected with Mycobacterium lepraemurium; four cultures were discarded early, three because of contamination and one because of poor initial uptake of bacteria. Three cultures were successfully maintained through several transfers and in two of them multiplication of bacteria was also maintained. The results of a representative experiment are now given in detail.

The bottle of cells was infected with $2 \cdot 4 \times 10^{9}$ bacteria and the following day the trypsinized cells were transferred to half test tubes. The object in this experiment was to expand the cultures gradually from small, through intermediate, to large containers as the number of cells increased, in this way keeping the cells in good condition but metabolizing slowly. Half test tubes were used for the first 17 days, 
Porter flasks to day 48 and Pyrex feeding bottles until the termination of the experiment on day 156. A much higher proportion (40-80\%) of cells was retained for transfer than in the type A experiments (Table 4).

The distribution of bacteria in the cells was again followed by counting the acid-fast bacteria in stained smears prepared at each transfer (Table 3 ). The initial uptake of bacteria was high, $84 \%$ of the cells being infected. The decrease in the proportion of infected cells throughout this experiment was much less than in the type $A$ experiments, and even from days 83 to 156 more than $50 \%$ of the cells contained bacteria.

Total acid-fast bacterial counts and the proportion of degenerate bacteria, seen in the electron microscope, are shown in Table 4. During the total culture period the 'apparent' increase in the number of bacteria was 59.4-fold or 5.9 generations, which gives an average generation time of $\mathbf{2 6} \cdot \mathbf{4}$ days. Allowing for the proportion

Table 3. Percentage of uninfected and infected rat fibroblast cells (strain 14pf) showing the distribution of intracellular acid-fast bacteria (type $\boldsymbol{B}$ experiment)

\begin{tabular}{|c|c|c|c|c|c|}
\hline \multirow{3}{*}{$\begin{array}{l}\text { Culture } \\
\text { period } \\
\text { (days) }\end{array}$} & \multicolumn{5}{|c|}{ No. of bacteria/cell } \\
\hline & 0 & $1-2$ & $3-5$ & $6-10$ & $>10$ \\
\hline & \multicolumn{5}{|c|}{ Infected cells (\%) } \\
\hline 0 & 16 & 10 & 8 & 6 & 60 \\
\hline 17 & 8 & 10 & 12 & 18 & 52 \\
\hline 48 & 18 & 14 & 26 & 16 & 26 \\
\hline 83 & 49 & 19 & 8 & 9 & 15 \\
\hline 106 & 31 & 22 & 19 & 9 & 19 \\
\hline 156 & 41 & 21 & 19 & 10 & 9 \\
\hline
\end{tabular}

Table 4. 'Apparent' and 'estimated' increase in the number of bacteria in cultures of rat fibroblast cells (strain 14 pf) during each subculture (type B experiment)

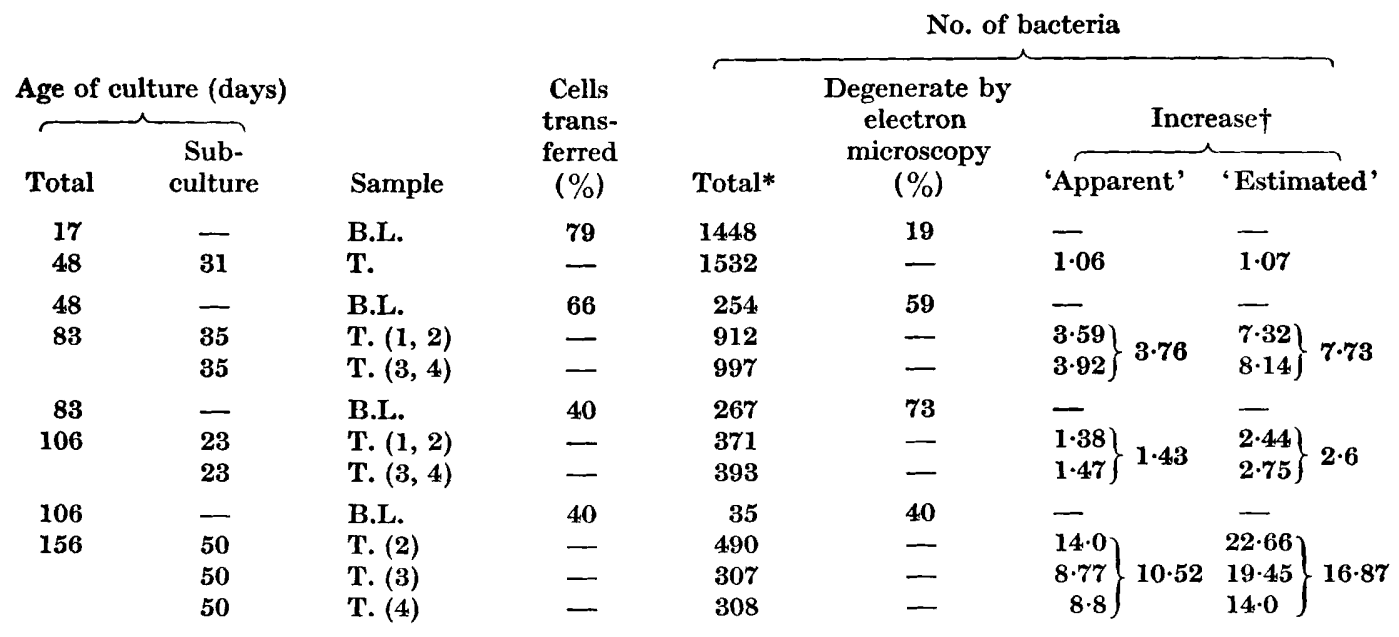

B.L. = base-line sample; T. = trypsinized sample, the bracketed number indicates individual bottles, soled or treated singly ; ${ }^{*}=$ total number of acid-fast bacilli $(X \log 5 \cdot 0755) ; \dagger=$ 'Apparent' increase derived om (total count T./total count B.L.); 'estimated' increase derived from (total count T. - no. degenerate bacilli B.L.); (total count B.L. - no. degenerate bacilli in B.L.). 
of degenerate bacteria in each sample, as determined in the electron microscope, the increase was greater-362.7-fold or $8 \cdot 4$ generations-which gives an average generation time of 18.6 days. The 'apparent' and 'estimated' increase in the bacterial population during each subculture are shown in Fig. 1.

Viability of Mycobacterium lepraemurium recovered from cell cultures. On days 83, 106 and 156 samples of bacteria from the cultures were inoculated subcutaneously into mice and all the animals subsequently developed typical skin lepromata, showing that the bacteria were still viable and had retained their infectivity.

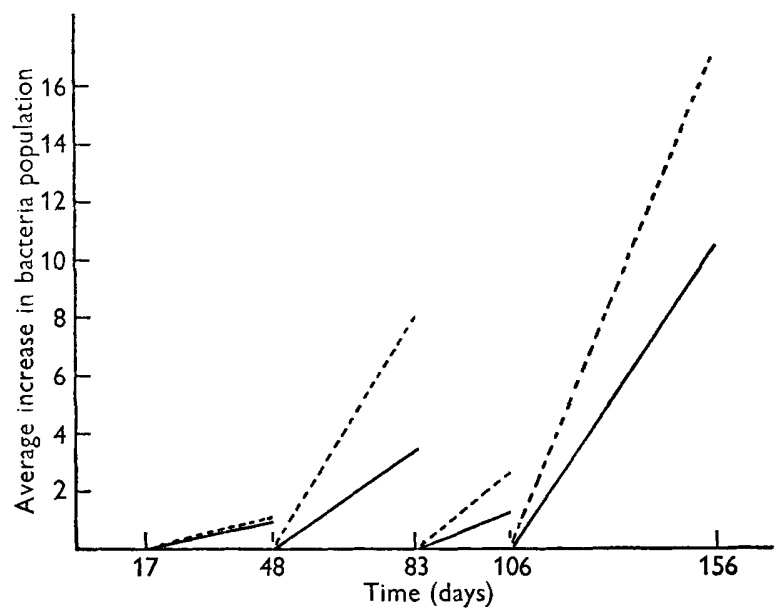

Fig. 1. 'Apparent' and 'Estimated' increase in the number of bacteria in rat fibroblast cells (strain 14 pf) during each subculture (type B experiment). —_Apparent' increase; - - 'estimated' increase.

\section{DISCUSSION}

This study shows, for the first time, that more continuous multiplication than hitherto of Mycobacterium lepraemurium can be achieved in vitro in tissue cultures. For example, the increase in the number of bacteria in several experiments was equivalent to 3 or 4 generations, and in one of the more successful experiments, the increase represented more than 8 generations. Hitherto, in our own work (Garbutt et al. 1958) and that of Wallace et al. (1958), multiplication of $M$. lepraemurium was generally confined to one generation. In the previous studies the cell cultures infected with mycobacteria were maintained for 2-6 weeks without subcultivation, whereas in the present work the infected cells were maintained for very much longer periods (up to 22 weeks) by repeatedly and regularly subculturing the infected cells. Since rat fibroblasts grow relatively slowly, particularly at $34^{\circ}$, new medium was required only every 10 days, but the cells were subcultured as soon as they showed deterioration, usually after 20 to 30 days. Changes in the bacterial populations were determined in each subculture period throughout the experiments. Although the methods were less accurate than those used in the earlier studies because of the necessity to transfer the cells from one container to another, they were sufficiently accurate to detect any significant multiplication. The individual culture periods were not less than 20 days; long enough to detect multiplication 
if the bacteria were dividing freely at the average dividing time of 10-13 days found in vivo. The results of one particular experiment show that under these conditions the bacteria can continue to multiply in subcultured cells for 156 days, and this experiment was terminated only because of contamination. Nevertheless, multiplication did not occur in all the experiments and even in the successful ones the bacteria did not multiply regularly in each subculture.

The host cells chosen for these studies, rat fibroblasts (strain 14 pf), were the same as those in which we had initiated successfully the growth of rat leprosy bacteria. The cell type used for growing rat leprosy bacteria may be important because, with identical methods of assessment, multiplication did not occur in these laboratories in mouse monocytes, in mouse fibroblasts (L-strain), with or without hydrocortisone or in monkey kidney cells. Nevertheless, it may be significant that growth of rat leprosy bacteria has been achieved only in cells derived from animal species susceptible to the infection. The rat fibroblasts are useful for long-term cultures because they can be adapted to grow slowly. Furthermore, they readily phagocytose rat leprosy bacteria and, under suitable conditions, 80-90\% of the cells can be infected. Normally fibroblasts will phagocytose the mycobacteria only in the presence of serum, but because serum has been shown to decrease the endogenous metabolism of Mycobacterium lepraemurium (Hanks \& Gray, 1954) methods were developed (E. W. Garbutt; unpublished) to avoid direct exposure of the bacteria to serum. It was found that $\boldsymbol{M}$. lepraemurium suspended in low concentrations of albumin were ingested by rat fibroblasts as readily as bacteria in a serum-containing substrate.

Rees et al. (1960) showed that electron microscopy can provide a quantitative guide to the viability of Mycobacterium lepraemurium by allowing dead forms to be identified. The method has been of great value in following the survival of bacteria in the tissue cultures, because rat leprosy bacteria, like other mycobacteria, still retain their ability to stain with carbol-fuchsin even when dead.

In earlier studies (Rees \& Wong, 1958; Garbutt et al. 1958) it was stressed that multiplication of Mycobacterium lepraemurium could be determined accurately only by counting the total number of stained bacteria in each culture; other methods based on the proportion of infected cells or the distribution of bacteria within cells would be inaccurate because of the changing cell populations. This point is particularly well demonstrated in Tables 1 and 3, showing, in 2 experiments, the distribution of bacteria in samples of cells taken at each subculture. In these experiments the rat fibroblasts were in good condition and were multiplying freely. However all the cells, infected or uninfected, were not necessarily dividing at the same rates. From days 106 to 156 (Table 3) the proportion of uninfected cells remained fairly steady and the proportion of heavily infected cells decreased, yet there was, in fact, an increase in the total number of bacteria. Furthermore, the results in Table 1 showed a continuous increase in the proportion of uninfected cells, yet again they did not show that, from time to time, the total number of bacteria in the cultures increased. The results indicated, however, that the rate of bacterial multiplication was much less than the rate of cell division.

The present studies show quite definitely that continuous multiplication can occur in infected cultures which are regularly subcultured, as depicted in the type $B$ experiments. In the type $\mathbf{A}$ experiments, although some multiplication was 
obtained in several of the subcultures, it was not maintained regularly, and furthermore the number of bacteria decreased throughout the culture period. The type $\mathbf{A}$ experiments, in fact, illustrate the problems arising when attempts are made to culture an intracellular parasite with a much longer division time than the host cell. While it is necessary to subculture in order to maintain a healthy population of host cells, the proportion of cells transferred at each subculture must be high enough to retain sufficient bacteria for counting. In the type A experiments approximately three-quarters of the cells were discarded at each transfer in order to avoid overcrowding of the cells, but it is obvious now that this was too high a proportion to leave sufficient bacteria for accurate counting, even when some multiplication of bacteria occurred. In the type $\mathrm{B}$ experiments, only a quarter of the cells were discarded at each transfer and even though this resulted in overcrowding of the cells the cultures could be maintained for 20 to 30 days and the problem of insufficient bacteria for accurate counting did not arise.

We particularly wish to thank Dr R. C. Valentine for examining and determining the proportion of degenerate leprosy bacteria in the electron microscope, Dr G. O. Gey for supplying the 14pf cultures and the staff at Victoria Maternity Hospital (Barnet, Hertfordshire) for the human cord serum. We also gratefully acknowledge the technical assistance of Mrs Moira Quiggin, Mrs Joan Barham and Mr C. V. Gibbs.

\section{REFERENCES}

Balfour-Jones, S. E. B. (1937). The experimental transmission of rat leprosy to the golden hamster (Cricetus auratus). J. Path. Bact. 45, 739.

Ehrmann, R. L. \& Gey, G. O. (1953). The use of cell colonies on glass for evaluating nutrition and growth in roller-tube cultures. J. nat. Canc. Inst. 13, 1099.

Garbutt, E. W., ReEs, R. J. W. \& BarR, Y. M. (1958). Multiplication of rat-leprosy bacilli in cultures of rat fibroblasts. Lancet, ii, 127.

Gey, G. O., Hanks, J. H. \& Barrett, R. (1948). Retardation of growth and metabolism of normal and malignant cells during continuous cultivation. Grozeth, 12, 69.

Hanks, J. H. \& Gray, C. T. (1954). The application of metabolic studies to leprosy research. Int. J. Leprosy, $22,147$.

HART, P. D'Arcy \& ReEs, R. J. W. (1960). Effect of macrocyclon in acute and chronic pulmonary tuberculous infection in mice as shown by viable and total bacterial counts. Brit. J. exp. Path. 41, 414.

Morgan, J. F., Morton, H. J. \& Parker, R. C. (1950). Nutrition of animal cells in tissue culture. 1. Initial studies on a synthetic medium. Proc. soc. exp. Biol., N.Y. 73, 1.

ReEs, R. J. W. (1957a). The chemotherapeutic activity of Triton WR 1339 and macrocyclon in murine leprosy. Amer. Rev. Tuberc. 76, 915.

REes, R. J. W. (1957b). Some experimental approaches to leprosy. E. Afr. med. J. 34, 361.

Rees, R. J. W. \& Wong, P. C. (1958). Limited multiplication of M. lepraemurium in tissue culture. Nature, Lond. 181, 359.

Rees, R. J. W., Valentine, R. C. \& Wong, P. C. (1960). Application of quantitative electron microscopy to the study of Mycobacterium lepraemurium and $\boldsymbol{M}$. leprae. J. gen. Microbiol. 22, 443.

Wallace, J. H., Elek, S. D. \& Hanks, J. H. (1958). Limited multiplication of Mycobacterium lepraemurium in cell cultures. Proc. Soc. exp. Biol., N.Y. 97, 101.

Wong, P. C. (1957). Study of the behaviour of Mycobacterium lepraemurium in the infected animal and in tissue culture. Ph.D. Thesis, University of London. 